Majken Korsager

Norwegian Centre for Science Education

Eldri Scheie

Norwegian Centre for Science Education

DOI: http://dx.doi.org/10.5617/adno. 6451

\title{
Students and education for sustainable development - what matters? A case study on students' sustainability consciousness derived from participating in an ESD project
}

\begin{abstract}
This article presents a qualitative case study exploring how students' participation in a project about sustainable development (SD) influences their sustainability consciousness. Sustainability consciousness is a concept that integrates the environmental, economic and social dimensions of SD with knowledge, skills and attitudes. This study follows up the results from a recent quantitative largescale study conducted in Sweden, investigating the impact of education for sustainable education (ESD) on students' sustainability consciousness. Results from our study show that the students' sustainability consciousness is dominated by a mono-dimensional approach from the environmental perspective. However, their motivation to act (Attitudes) was highest within the economic dimension. The skills they expressed they had attained, were mainly practical and mostly within the environmental dimension and to some extent the social dimension. Analysis of the project showed both a lack of collaboration between the teachers and a lack of explicit teaching, which could explain why the holistic approach to SD was under-communicated to the students. The students' sustainability consciousness seemed improved after a re-design of the ESD project, where the main changes were more explicit teaching and learning goals, and adding Norwegian as a subject. The results are discussed in relation to what should be emphasized in ESD projects in order to empower pupils and students for action competence for $S D$.
\end{abstract}

Keywords: education for sustainable development, students' sustainability consciousness 


\section{Elever og utdanning for bærekraftig utvikling - hva er viktig? En case-studie om elevers bærekraftbevissthet etter deltakelse $i$ et prosjekt om bærekraftig utvikling}

\section{Sammendrag}

Denne artikkelen presenterer en kvalitativ case-studie som utforsker hvordan elevers deltakelse $i$ et prosjekt om borekraftig utvikling påvirker deres borekraftbevissthet. Bcerekraftbevissthet er et konsept som integrerer den miljømessige, økonomiske og sosiale dimensjonen av barekraftig utvikling med kunnskap, ferdigheter og holdninger. Denne studien følger opp resultatene fra en nylig kvantitativ storskalaundersøkelse gjennomført $i$ Sverige, der effekten av utdanning for borekraftig utvikling (UBU) på elevers borekraftbevissthet er undersøkt. Resultatene fra denne studien viser at elevenes borekraftbevissthet domineres av en mono-dimensjonal tilnoerming fra miljøperspektivet. Men deres motivasjon til å handle (Holdninger) var høyest innenfor den økonomiske dimensjonen. De ferdighetene de uttrykte de hadde oppnådd, var hovedsakelig praktiske og for det meste innenfor miljødimensjonen og noen innen den sosiale dimensjonen. Analyse av prosjektet viste at det var både mangel på samarbeid mellom loererne og mangel på eksplisitt undervisning, noe som kunne forklare hvorfor den holistiske tilnoermingen til boerekraftig utvikling ble underkommunisert til elevene. Elevenes barekraftbevissthet ble forbedret noe etter re-design av prosjektet, hvor hovedendringene var mer eksplisitt undervisning og loeringsmål samt å inkludere norsk som emne. Resultatene diskuteres med sikte på hva som bør vektlegges i prosjekter $i$ borekraftig utvikling for å gi elever og studenter handlingskompetanse i borekraftig utvikling.

Nøkkelord: utdanning for barekraftig utvikling, elevers barekraftbevissthet

\section{Introduction}

This paper presents a qualitative case study exploring students' sustainability consciousness after participating in an education for sustainable development (ESD) project. In order to support schools and teachers in implementing ESD, a number of international organizations and networks such as ASPnet ${ }^{1}$ and EcoSchools ${ }^{2}$ have been established. In addition, Norwegian schools may join the national initiative known as the Sustainable Backpack ${ }^{3}$. Schools in the Sustainable

\footnotetext{
${ }^{1} \mathrm{http}: / /$ unesco.no/utdanning/skolenettverket/

2 https://grontflagg.fee.no/ecoschools-internasjonalt/

${ }^{3}$ https://www.natursekken.no/c1187995/artikkel/vis.html?tid=2102111
} 
Backpack get help in designing their own ESD project, supported by guidelines found in the ESD literature (Breiting \& Mayer, 2015; UNESCO, 2017).

This study follows up the results from a recent large quantitative study conducted in Sweden, which investigated the impact of ESD on students' sustainability consciousness (Olsson, Gericke, \& Chang Rundgren, 2016). Sustainability consciousness is a concept that integrates the environmental, economic, and social dimensions of sustainable development with knowingness, attitudes, and behaviors. According to Olsson et al. (2016), knowingness refers to the fundamentals on which sustainable development (SD) is based, including facts, skills, understanding, and experiences. The results of the Swedish study indicated that schools with an explicit ESD profile (ESD schools) had only a minor impact on the students' sustainability consciousness in grade 6 and even a negative impact on students in grade 9. Similar results were found in another Swedish study, in which young students' perception of issues regarding ESD in "Green outdoor schools", "ESD schools", and "Non-green-profile schools" was explored (Manni, Ottander, Sporre, \& Parchmann, 2013). The statistical results indicated some interrelation between students' experienced cognitive, emotional, social, and situated aspects of learning; however, there was no significant difference between students' outcomes in the different types of school.

Both of these Swedish studies suggest that, in spite of efforts to implement ESD in schools, the outcome in terms of students' sustainability consciousness is not significantly improved. Consequently, it was not to be anticipated that schools that follow ESD guidelines would succeed in accomplishing the aim of ESD, which, according to UNESCO, is developing competencies that empower individuals to reflect on their own actions (UNESCO, 2017, p. 7). Olsson et al. (2016) concluded that, even though the schools in the study were so-called "ESD schools", they may have operationalized the ESD guidelines differently. Manni et al. (2013) attributed their results to a lack of explicit teaching approaches.

Hitherto there have been, to our knowledge, only a few Norwegian studies researching ESD and the impact on students' outcomes. In an external evaluation of the Sustainable Backpack in 2014 (Sjaastad, Carlsten, Opheim, \& Jensen, 2014), a survey of 667 students and 192 teachers was conducted. The evaluation concluded that the students had improved knowledge, attitudes, and skills related to sustainable development. A recent study investigated the significance of using the local environment in ESD in some schools participating in the Sustainable Backpack (Gabrielsen \& Korsager, 2018). Teachers interviewed reported that the use of the local environment in ESD was especially effective in producing an impact on students. Nevertheless, we have little knowledge about what really matters in the design of ESD projects that impact positively on students.

The purpose of this case study is therefore to explore what outcome students get from participating in an education for sustainable development (ESD) project and hence try to explain these outcomes. The following research questions are posed: 
RQ1: In what ways do students express sustainability consciousness after participating in an ESD project?

RQ2: What characterizes the teaching in the ESD project in which the students participated?

In the following sections, the concepts of SD, ESD, and sustainability consciousness are elaborated as background for the analytic framework used in this study.

\section{Sustainable Development (SD)}

The concept of SD can be defined as development that meets the needs of the present without compromising the ability of future generations to meet their own needs (World Commission on Environment and Development (WCED), 1987), also known as the Brundtland definition. Although this definition has been criticized for being too broad (Hesselink, van Kempen, \& Wals, 2000), it clearly focuses on development and hence implies an interaction between environmental, social, and economic dimensions now and in the future (UNESCO, 2006). Whereas the environmental dimension comprises biological diversity, ecosystem resiliencies, natural resources, and climate change, as well as awareness of the resources and fragility of the physical environment, the social dimension concerns areas related to society, such as human rights, peace, health, gender equality, and intercultural understanding. The social dimension hence emphasizes equality of security and health among people in different populations, in the present and in future generations (Van den Bergh, 2007). SD within the economic dimension concerns poverty, the market economy, and economic responsibility.

It is increasingly understood that to attain SD, these three dimensions must be seen in a holistic way, meaning that the environmental, economic, and social dimensions should all be considered as equally important (Corney, 2006; Summers \& Childs, 2007; UNESCO, 2005). A holistic understanding of SD implies that the environmental, economic, and social dimensions are intertwined and indivisible (Figure 1) (Dale \& Newman, 2005; De Haan, 2006; Koppelman, 2013; Van den Bergh, 2007).

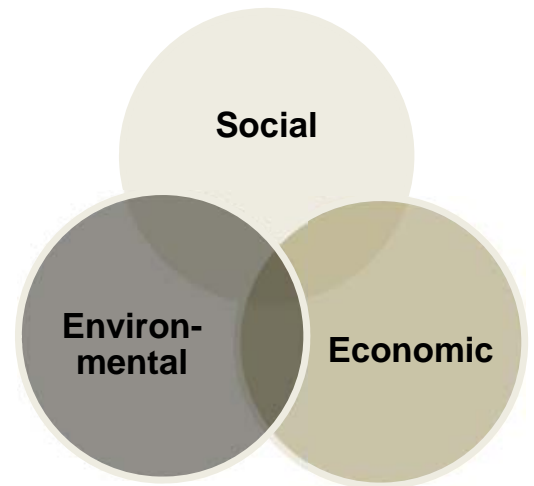

Figure 1. The environmental, economic, and social dimensions of sustainable development are intertwined and cannot be separated within a holistic understanding. 
Furthermore, the holistic approach includes interrelationships in time and space (Wals, 2012). Time implies the economic, environmental, and social dimensions in the past, present, and future, whereas space refers to geographic relationships from the near and local context to the distant global context.

\section{Education for Sustainable Development (ESD)}

ESD comprises the process of implementing SD in schools (Ohman, Ostman, \& Sandell, 2005; Wals, 2011). As described in the previous section, SD is not restricted to environmental issues, which means that ESD differs from environmental education (EE). In EE, the focus is on the natural environment and management to conserve and preserve nature (UNESCO, 2006). ESD also concerns management, but with an emphasis on development rather than conservation and in an interdisciplinary manner, implying that SD is a topic that could be encompassed within almost all disciplines.

The process of implementing ESD has been going on for several decades, but since the beginning of the Decade on Education for Sustainable Development in 2005 (UNESCO, 2005), SD has been introduced into education programs worldwide. In Norway, SD is contained in both the objectives and the competence aims in social science and natural science, but is also among the main objectives of the educational system overall (Utdanningsdirektoratet, 2010).

In parallel with the implementation of ESD, several sets of guidelines have been published (Breiting, Mayer, \& Mogensen, 2005; Mogensen \& Schnack, 2010; UNECE, 2011; UNESCO, 2017). These concern everything from organizational matters to teaching approaches and learning outcomes. In 2015, the "2030 Agenda for Sustainable Development", which included the 17 Sustainable Development Goals, was adopted by the 193 countries of the UN General Assembly. The Agenda is a commitment to eradicate poverty and achieve sustainable development worldwide by 2030. Along with the 2030 Agenda (UN, 2015), a document designed as a guide to ESD relating to the 17 Sustainable Development Goals was published (UNESCO, 2017), with the aim of promoting education as the key to SD. In line with earlier guidelines, this guide suggests that ESD, in addition to the content taught, should also facilitate learner-centered teaching that encourages participation, collaboration, problem-solving, multi- and interdisciplinary learning, and the linking of formal and informal learning (ibid., p. 7).

\section{Student Outcomes in ESD}

The existing guidelines for designing an ESD project are general and overarching and can hence be operationalized in several ways. Although there may be large variations within ESD and in how ESD projects are designed, there is a consensus that ESD aims to develop competencies that empower individuals to act (UNESCO, 2017, p. 7). To be empowered is sometimes referred to as "action competence" (Breiting \& Mogensen, 1999; Jensen \& Schnack, 1997). The concept of action competence in ESD refers to: knowing how to take action, 
confidence in having an influence, the desire to act, and knowledge about the issues to act on (Mogensen \& Schnack, 2010).

The integration of both cognitive and affective aspects of environmental education, such as beliefs, attitudes, knowledge, and behaviors, has been referred to by several researchers as environmental consciousness (Kollmuss \& Agyeman, 2002; Lafuente \& Sánchez, 2010). Within ESD, the concept of sustainability consciousness (Berglund, Gericke, \& Chang Rundgren, 2014; Olsson et al., 2016), is defined as a consciousness that integrates the environmental, economic, and social content of SD with the elements of competencies to act, namely knowingness, attitudes, and behaviors. In this study, a modified version of sustainable consciousness is applied as an analytic framework.

\section{Sustainability Consciousness as an Analytic Framework}

The term "competence" carries different definitions and understandings in daily life, in academic disciplines, and in management documents (Prøitz, 2014; Weinert, 2001). However, a common feature of most definitions is that competence is about the ability of individuals to use their knowledge and skills to solve tasks or meet challenges in certain contexts (Rychen \& Salganik, 2003; Weinert, 2001). When defining the process of developing competencies, it is common to distinguish between acquiring knowledge and developing skills (Schneider \& Stern, 2010). Such a distinction is also made in the Norwegian context, where knowledge and skills are seen as separate elements in the competence definition (Kunnskapsdepartementet, 2016) and in the competence aims in the curriculum (Utdanningsdirektoratet, 2006). In this study, "knowingness" is therefore replaced by knowledge and skills.

Knowledge is about understanding and recognizing concepts, ideas, phenomena, theories, facts, principles, or procedures within a topic or an area. A skill can be defined as the "ability to apply knowledge to solve problems or tasks" and includes both practical and cognitive skills. Practical skills are the procedures a person is able to perform individually or in collaboration with others. The ability to collaborate is also defined as a skill. Cognitive skills entail the ability to analyze and evaluate, and include systems thinking, critical thinking, and problem solving (De Haan, 2006; Schneider \& Stern, 2010).

A broader definition of competences includes attitudes and emotional aspects of learning (Breiting \& Mogensen, 1999; De Corte, 2010; Heckman \& Kautz, 2013; Kollmuss \& Agyeman, 2002). In relation to ESD, affective aspects of learning are especially relevant, because a person's attitude might determine whether he or she will actually contribute actions toward sustainable development. In Olsson's framework (Olsson et al., 2016), attitudes are defined as valueloaded feelings, whereas behaviors are intentions to act. However, attitudes and behaviors, in the sense of intentions, often overlap and merge, making it difficult to distinguish between them (Kollmuss \& Agyeman, 2002). Hence, behaviors are merged with attitudes, the category attitudes thus referring to feelings and the 
willingness, hope, and desire to act (Erstad, Amdam, Arnseth \& Silseth, 2014; Skolverket, 2013).

The modified version of sustainable consciousness used as an analytic framework in this study, is shown in Figure 2.

\begin{tabular}{|c|c|c|c|}
\hline SD Dimensions & $\begin{array}{l}\text { Knowledge } \\
\text { e.g., facts, } \\
\text { understanding } \\
\text { and experiences }\end{array}$ & $\begin{array}{l}\text { Skills } \\
\text { e.g., practical } \\
\text { and cognitive } \\
\text { skills }\end{array}$ & $\begin{array}{l}\text { Attitudes } \\
\text { e.g., feelings, } \\
\text { willingness, } \\
\text { hopes, and } \\
\text { wishes to act }\end{array}$ \\
\hline $\begin{array}{l}\text { Social } \\
\text { e.g., human rights, peace, } \\
\text { health, gender equality, } \\
\text { intercultural understanding }\end{array}$ & & & \\
\hline $\begin{array}{l}\text { Economic } \\
\text { e.g., poverty, market } \\
\text { economy, economic } \\
\text { responsibility }\end{array}$ & & & \\
\hline $\begin{array}{l}\text { Environmental } \\
\text { e.g., biological diversity, } \\
\text { ecosystem resiliencies, } \\
\text { natural resources, climate } \\
\text { change }\end{array}$ & & & \\
\hline
\end{tabular}

Figure 2. Analytic framework for sustainability consciousness (modified from Olsson et al., 2016), a concept that integrates the dimensions of SD - social, economic, and environmental - with the elements of competencies to act - knowledge, skills, and attitudes.

The students' expressions were assessed according to SD content, meaning their ability to consider environmental, economic, and social dimensions. These were categorized as mono-, bi-, or tri-dimensional, the latter being a synonym for the holistic approach to SD (Pauw, Gericke, Olsson, \& Berglund, 2015).

\section{Methods}

\section{The ESD project}

This qualitative case study was carried out in a rural upper secondary school, which participated in the Sustainable Backpack program. Mandatory requirements for the design of the ESD project for all schools in the Sustainable Backpack at the time of the study were that the teaching should be inquiry-based and multidisciplinary, including at least one science or social science subject. The schools were also encouraged, but not obliged, to use the local environment and collaborate with external partners. Beyond these general guidelines, the schools were free to design their ESD project as they wanted.

The school in the present study chose to work on sustainable development issues in a national park, which, being close to the school, could be defined as part of the school's local environment. The aim of the ESD project was to raise the 
students' motivation, engagement, and understanding of sustainable management and sustainable outdoor recreation in the area. The ESD project started with a three-day-long camping trip in the park in the autumn, while the rest of the project was integrated into the ordinary curriculum in science, sport, and outdoor life, as well as Norwegian in the second year of this study. During the field trip, the school collaborated with supervisors from the Norwegian Nature Inspectorate, who taught the students theoretically and practically about the management of nature, various species, and hunting traditions and culture. The inquiry activities included planning and conducting fieldwork during the trip, as well as analyzing data from observations of different species and gradient analysis of the flora. The results of the analyses were communicated in a report and an oral presentation.

\section{Participants and data}

The participants were 20 students from grade 11 (first grade of upper secondary school, age 16) and three teachers of science, sport, and mathematics. The data in this study were collected during the second year of the school's participation in the Sustainable Backpack program. The teachers were given feedback and supervision after initial analysis of the student outcomes, which resulted in a redesign of the ESD project the following year. See Figure 3.

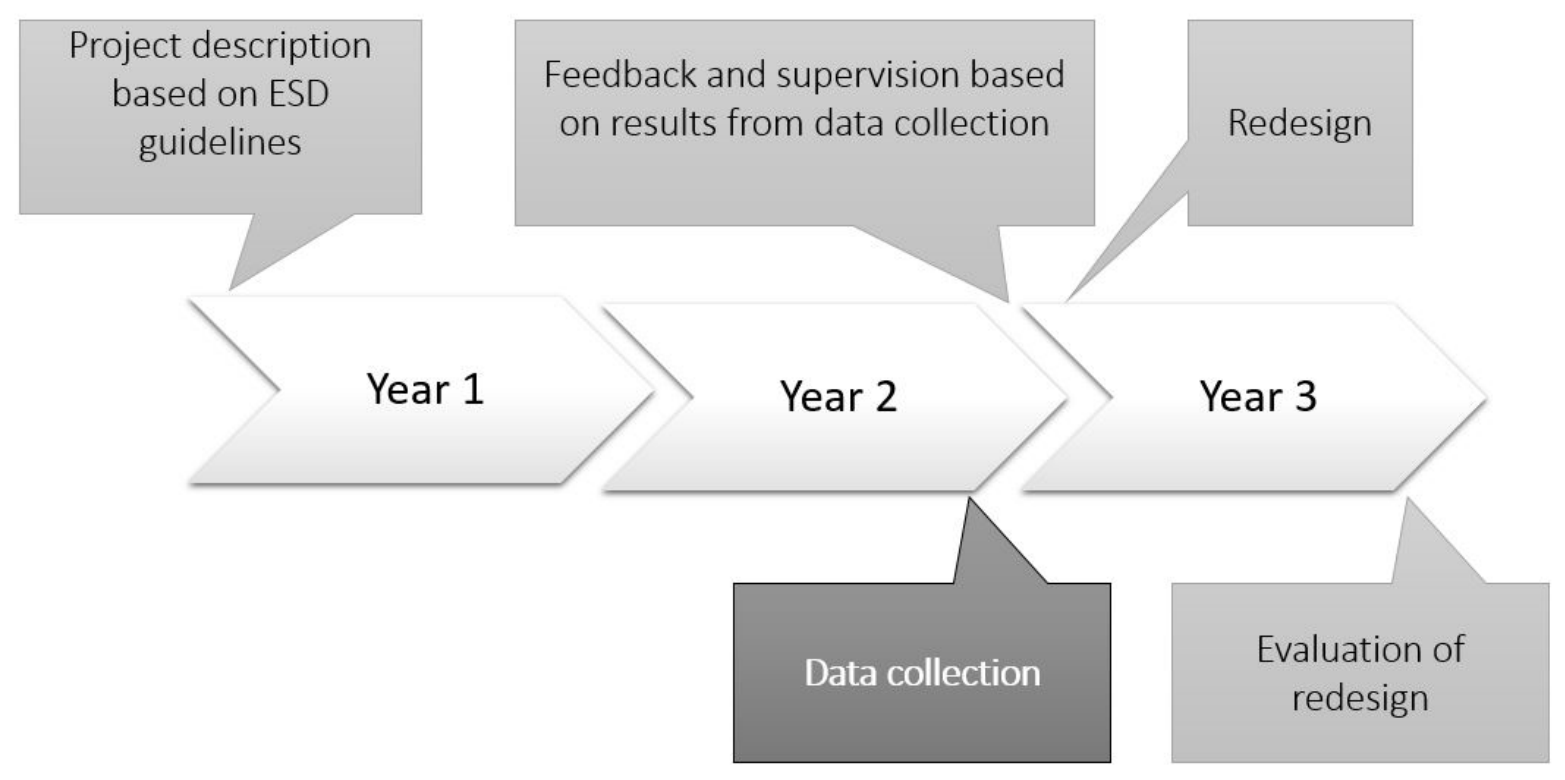

Figure 3. Overview of the school's work with their ESD project (upper boxes) and data collection for research and evaluation (lower boxes). Years 1, 2, and 3 (in the middle) are the school years in which the school participated in the Sustainable Backpack program.

In order to answer the research questions, qualitative data were collected from different sources, including observations, group interviews, a survey, a crossform, and, from the teachers, a project description (Table 1). 
Table 1. Overview of the data collected in this study

\begin{tabular}{|l|l|l|}
\hline Data & Participants & Description \\
\hline STUDENTS & $\begin{array}{l}\text { Obser- } \\
\text { vations } \\
\text { 20 students } \\
\text { in total }\end{array}$ & $\begin{array}{l}\text { Observation of the students' oral presentations of their fieldwork. Each } \\
\text { presentation lasted for approximately 10 minutes. }\end{array}$ \\
\hline $\begin{array}{l}\text { Group } \\
\text { interviews }\end{array}$ & $\begin{array}{l}\text { Two groups } \\
\text { with four } \\
\text { students in } \\
\text { each }\end{array}$ & $\begin{array}{l}\text { Semi-structured group interviews. Each interview lasted approximately } \\
\text { 30 minutes. The two authors conducted the interviews together. All } \\
\text { interviews were audio-recorded and subsequently transcribed by another } \\
\text { person. }\end{array}$ \\
\hline Survey & $\begin{array}{l}\text { Individual } \\
\text { answers from } \\
20 \text { students }\end{array}$ & $\begin{array}{l}\text { The students answered a survey consisting of a mix of multiple-choice } \\
\text { questions, statements, and open-ended questions about sustainable } \\
\text { development. 42 items in total. }\end{array}$ \\
\hline Cross-form & $\begin{array}{l}\text { Individual } \\
\text { answers from } \\
18 \text { students }\end{array}$ & $\begin{array}{l}\text { The cross-form consisted of 16 competencies (six knowledge, four } \\
\text { attitudes, six skills) the teachers claimed were taught and trained, and the } \\
\text { students' task was to confirm or refute these claims. If confirmed, they } \\
\text { were asked to relate how they acquired these competencies (draw lines) } \\
\text { to specific learning activities. Competencies were listed in a left aligned } \\
\text { column and learning activities in a right aligned column; "crosses" occur } \\
\text { when students draw lines between them. }\end{array}$ \\
\hline TEACHERS & $\begin{array}{l}\mid l \\
\text { One group of } \\
\text { three } \\
\text { teachers }\end{array}$ & $\begin{array}{l}\text { Semi-structured group interview conducted with three teachers of } \\
\text { science, sport, and mathematics. The interview lasted approximately an } \\
\text { hour. The two authors conducted the interview together. The interview } \\
\text { was audio-recorded and subsequently transcribed by another person. }\end{array}$ \\
\hline $\begin{array}{l}\text { interview } \\
\text { Project } \\
\text { description }\end{array}$ & $\begin{array}{l}\text { Written description in which the teachers described the ESD project, } \\
\text { including the subjects to be taught and intended learning outcomes for } \\
\text { the students. }\end{array}$ \\
\hline
\end{tabular}

The project description was analyzed prior to the data collection to guide the design of the survey, the interviews, and the cross-form. The questions and statements in the survey were designed to assess the students' knowledge about the concept of SD, in addition to their competencies to act in terms of how informed, empowered, and motivated they were (Vare \& Scott, 2007). By combining multiple-choice questions and statements with open-ended questions, the survey aimed to assess the students' perception of specific topics, while also allowing them to add their own thoughts and ideas.

The semi-structured group interviews were audio-recorded and later transcribed and analyzed. The quotes from the interviews presented in this paper are hence translated from Norwegian into English. All names are pseudonyms to ensure anonymity.

Data from the observations, cross-form, survey, and group interviews with the students were triangulated to answer RQ1, using the analytic framework of sustainability consciousness. Data from the cross-form, group interview with the teachers, and project description were triangulated to answer RQ2. The triangulation of data was intended to assure high validity of the research by capturing different dimensions of the same phenomenon, while also cross-validating the data (Silverman, 2009, p. 294). 
During the spring of School year 3, an evaluation of the redesigned project was carried out (Figure 3). The evaluation reviewed the survey results from 21 students, a group interview with two teachers (one of science and one of sport), and new project description describing the redesign. Owing to the limited amount of data, it was not possible to triangulate and hence validate the findings after the redesign. The results from the evaluation do not therefore qualify as valid data, but indications from the evaluation are discussed.

\section{Results}

\section{Knowledge}

In the survey, the students were asked two questions with three alternative answers: What is the Brundtland definition of sustainable development ${ }^{4}$ ? and What must be taken into account to attain sustainability? The results show that 18 of the 20 students knew the correct definition. However, none of the students answered that social and economic dimensions should be taken into account to attain sustainability (Figure 4). This result indicates a mono-dimensional understanding, where only the environmental dimension is considered.

\section{What must be taken into account to attain sustainability?}

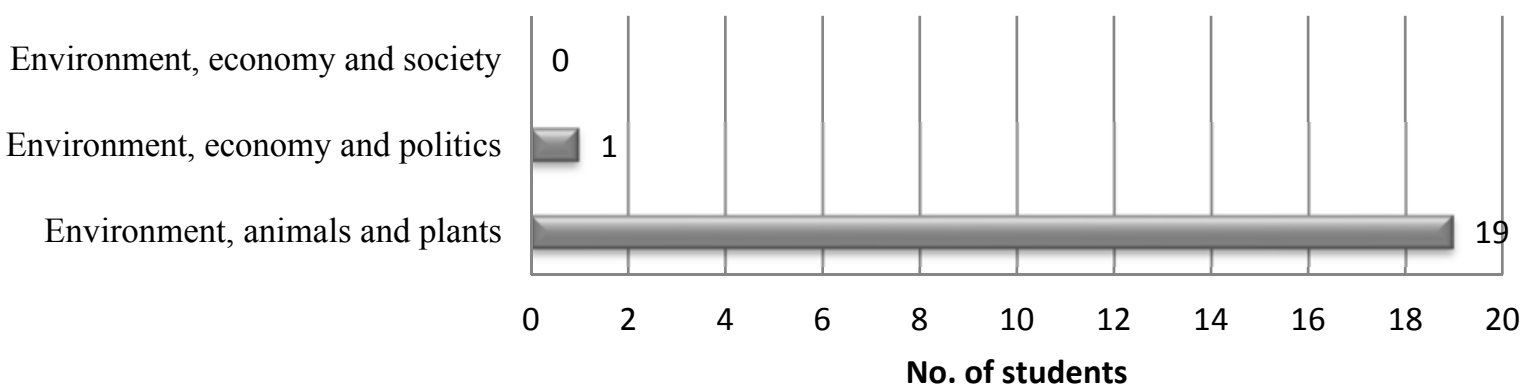

Figure 4. Students' ( $\mathrm{n}=20)$ answers to the survey question: What must be taken into account to attain sustainability?

The questions were followed by four statements (Table 2). Ten students agreed with the statement that $S D$ is about saving nature at any cost, whereas only three disagreed and seven neither agreed nor disagreed. Answers to this question also indicate a mono-dimensional understanding from the environmental point of view. However, 12 students agreed with the statement that $S D$ is about finding compromises that take into account both social and economic conditions for people, while protecting nature, indicating a tri-dimensional, integrated understanding. However, six of the students agreed with both, indicating a cognitive conflict in these students' understanding of sustainable development. Two students agreed with the statement that $S D$ is about doing what is best for human

\footnotetext{
4 "Sustainable development is a development which meets the needs of current generations without compromising the ability of future generations to meet their own needs." (WCED, 1987).
} 
beings. These answers also indicate a mono-dimensional understanding, but from a social point of view.

Table 2. Students' $(n=20)$ answers to four statements in the survey

\begin{tabular}{lccc}
\hline Statement & Agree & $\begin{array}{c}\text { Neither agree } \\
\text { nor disagree }\end{array}$ & Disagree \\
\hline SD is about saving nature at any cost. & 10 & 7 & 3 \\
$\begin{array}{l}\text { SD is about doing what is best for human beings. } \\
\text { SD is about finding compromises that take into account } \\
\text { both social and economic conditions for people, while } \\
\text { protecting nature. }\end{array}$ & 2 & 14 & 4 \\
$\begin{array}{l}\text { There is a difference between working for sustainable } \\
\text { development and being an environmentalist. }\end{array}$ & 7 & 8 & 0 \\
\hline
\end{tabular}

Agreement with the statement that There is a difference between working for $S D$ and being an environmentalist suggests a more than mono-dimensional understanding, but, in the absence of any follow-up question, we can deduce no information about what the students who agreed, think are the differences, and hence no evidence of a bi- or tri-dimensional understanding.

At the end of the survey, the students were asked to give their own suggestions for actions to attain SD. These were categorized within the three SD dimensions, and the results show that the suggestions were mainly in the environmental dimension, such as recycling, saving energy, and using public transport. Some suggestions could be categorized as bi-dimensional, such as biking and walking (environmental and social - health), perhaps even tri-dimensional (environmental, social - health, and economic - reducing cost), but, since the underlying arguments were missing, it was not possible to categorize these suggestions.

The environmental dimension was also dominant in the students' oral presentations. Some groups presented a gradient analysis of the flora on the mountain ridge, whereas others had explored the size of fish in a mountain lake. However, none of the presentations included reflections in relation to environmental issues from the point of view of human impact or in any economic or societal context. Consequently, all the data from the observations of the students' presentations were coded as mono-dimensional from the environmental perspective.

Since the main focus of the ESD project was concern about SD and the management of the national park in the municipality, it was expected that the students would be able to offer reflections on the SD concept. The students were hence asked in the interviews to explain their understanding of SD. The following quotation is from one of the group interviews with students:

Ole: It is right that we of this generation should leave nature, plants, and the environment

[to the next generation] in a slightly better condition.

The student's explanation seems to arise from the Brundtland definition, which encompasses the social and the environmental dimensions. The explanation can hence be categorized as bi-dimensional. In contrast, another student in the same 
group interview gave a purely mono-dimensional explanation from the environmental point of view:

Lars: Isn't it that we should take care of all species ...? So they do not become extinct due to pollution and things like that?

The majority of the answers in both interviews were mono-dimensional from the environmental point of view, even when the interviewer asked the students to connect the concept of SD to the national park they had been exploring.

Interviewer: So, what does it mean to have SD in your local national park, then? Related to what you just said...

Ole: That ... the animals, the reindeer, and polar foxes, and so on, manage to survive themselves. That they do not have to be fed by humans, for example, like they are now.

Interviewer: Okay, anything else?

Sofie: And that, yes, just that they have enough food and that everything can be done like it has been before, really. And that no [species] is becoming extinct just because there is too little food or they are having too many babies so they won't get enough food.

Even when the interviewer explicitly asked for other dimensions, the students were uncertain and failed to answer. However, when the interviewer mentioned the students' main interest, alpine skiing, they started to consider the social dimension.

Interviewer: What does SD have to do with your sport? Does it have anything to do with it?

Erik: Yes ... global warming. That, in a way, if it's getting warmer on earth, there may be unstable snow conditions and so on.

Interviewer: What will that mean to you? Like, let's say it keeps getting hotter and there's less and less snow: what does that mean to you personally?

Erik: It'll be getting boring in the winter, then. Cold but no snow, maybe more rain.

Lars: Mm. That means a lot when we rely on snow. And we love skiing, snow, and ... We're addicted to snow.

Lars: In addition, if we are going to think further ahead, for example, children who want to go skiing, so it's important that they get the same opportunity, in a way.

Interviewer: So, do you agree that SD it not just about taking care of nature for nature's sake? But it is important for your life too?

Lars: Yes! 


\section{Skills}

Skills were self-reported from the interviews and the cross-form. In the crossform, the majority of the students answered in the positive to having practical skills such as being able to collaborate, live outdoors, and conduct fieldwork, but less than half the students answered that they had acquired cognitive skills such as systems thinking, sustainable nature management, and the management of predators in the past, present, and future. In the interviews, the students also mentioned practical skills they had acquired through the ESD project. An example is this student talking about the camping trip:

Karl: The first night we just set up the campsite, and the day after, everyone went to perform their tasks. I was responsible for the gradient analysis. Afterward, we learned how to write up a report on the fieldwork.

A skill that several of the students mentioned, was collaboration. The students had to collaborate in both practical tasks such as planning the trip and theoretical tasks such as analyzing data, writing the report, and presenting results. Even though several of the self-reported skills, such as outdoor living, data collection, and report writing, could be relevant for action competence for SD, these skills were mainly practical skills. Cognitive skills were largely limited to some systems thinking, whereas other skills such as critical thinking seemed absent.

\section{Attitudes}

Table 3. Students' responses to what they know they can do to contribute to SD and what they want to $d o$ (in \%). The third column shows the decline in percentage points from what they know to what they want to do.

\begin{tabular}{lccc}
\hline Action & $\begin{array}{c}\text { I know I can } \\
\text { contribute to } \\
\text { SD, by: }\end{array}$ & $\begin{array}{c}\text { I want to } \\
\text { contribute to } \\
\text { SD, by: }\end{array}$ & $\begin{array}{c}\text { Decline in percentage } \\
\text { points from know to } \\
\text { want to }\end{array}$ \\
\hline Sorting waste & 90 & 80 & 10 \\
\hline Saving energy & 85 & 75 & 10 \\
\hline $\begin{array}{l}\text { Reusing objects and clothes } \\
\text { Using public transport }\end{array}$ & 95 & 70 & 25 \\
\hline $\begin{array}{l}\text { Keeping myself updated on local, } \\
\text { national, and global environmental } \\
\text { issues }\end{array}$ & 90 & 55 & 35 \\
$\begin{array}{l}\text { Enlightening and teaching others } \\
\text { about SD }\end{array}$ & 79 & 55 & 24 \\
\hline Shopping less & 85 & 40 & 45 \\
\hline $\begin{array}{l}\text { Buying and eating Fairtrade foods } \\
\text { Volunteering }\end{array}$ & 60 & 40 & 20 \\
$\begin{array}{l}\text { Voting for green policies (when I'm } \\
\text { old enough) }\end{array}$ & 45 & 40 & 5 \\
\hline $\begin{array}{l}\text { Eating less meat } \\
\text { Having an education that enables } \\
\text { me to contribute to SD }\end{array}$ & 68 & 37 & 58 \\
\hline Buying locally produced food & 53 & 35 & 33 \\
\hline
\end{tabular}


The students' answers to what they considered (I know) as actions for SD in response to predefined suggestions are shown in Table 3 . The most supported actions were reusing objects and clothes $(95 \%)$, volunteering $(95 \%)$, sorting waste $(90 \%)$, and using public transport $(90 \%)$, whereas the two least supported suggestions were buying Fairtrade products (45\%) and buying locally produced food $(30 \%)$. When the results of what the students know about how they can contribute to SD were compared with what they want to do, there was a decline, which ranged from $5 \%$ to $58 \%$.

When the suggestions were categorized within the three SD dimensions, the results show that the students were more willing to contribute to SD by economic actions than environmental and social actions (Figure 5).

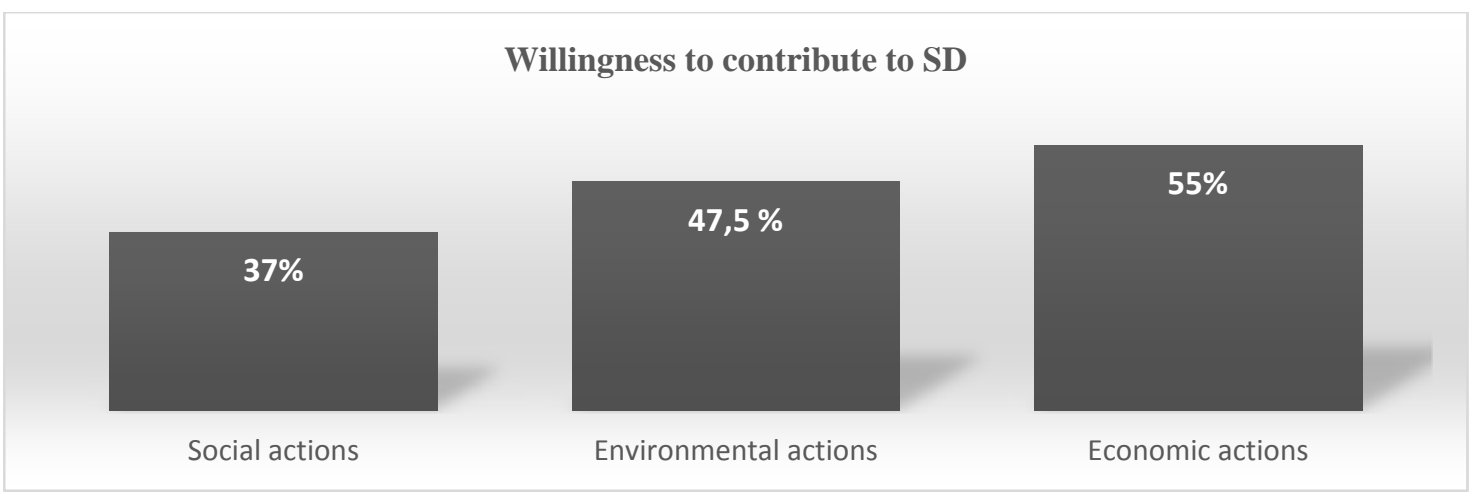

Figure 5. Students' stated willingness to contribute to SD, categorized into the three SD dimensions: social actions, environmental actions and economic actions.

In answer to an open-ended question in which the students were asked to describe three things that they already do or want to do to contribute to SD (attitudes), 53 suggestions were environmental, three were social, and none were economic. However, when asked what they thought was the most important thing a person can do to contribute to $\mathrm{SD}$, ten out of 13 suggestions were social actions such as informing and educating people by various means.

In the interviews, the students mentioned affective values several times, especially when talking about the field trip in the mountains.

Ole: Yes, I was a little bit more negative before I went on the trip than after. We spent some time on the gradient analysis, and had almost no spare time, but it was fun, really.

Marie: Spending some time out of school and doing something different was a lot of fun.

The students also mentioned how they were motivated to learn because of being outdoors.

Ida: Yes, we learned a lot about different species of lichen; that was actually interesting.

Lars: Yes, the lady who taught us about lichens was a great expert, which was good because we kind of understood more then. 
Lars: And she could tell us a lot about how to conduct the analysis; it was very good, because I remember that very well. Also, it was fun, really, just being on a trip. Being outdoors, instead of sitting in a classroom.

Karl: Yes, really ... I agree. It was fun. Being out in nature, and seeing how it is in reality instead of just learning about it.

The students had a distinct awareness of their obligation to contribute to SD but their motivation and willingness were less than their knowledge.

\section{Summary of results on RQ1}

A summary of the results on students' sustainability consciousness after triangulation of data is given in Figure 6. The color coding indicates the extent to which the different dimensions and perspectives were present in the entire coded data.

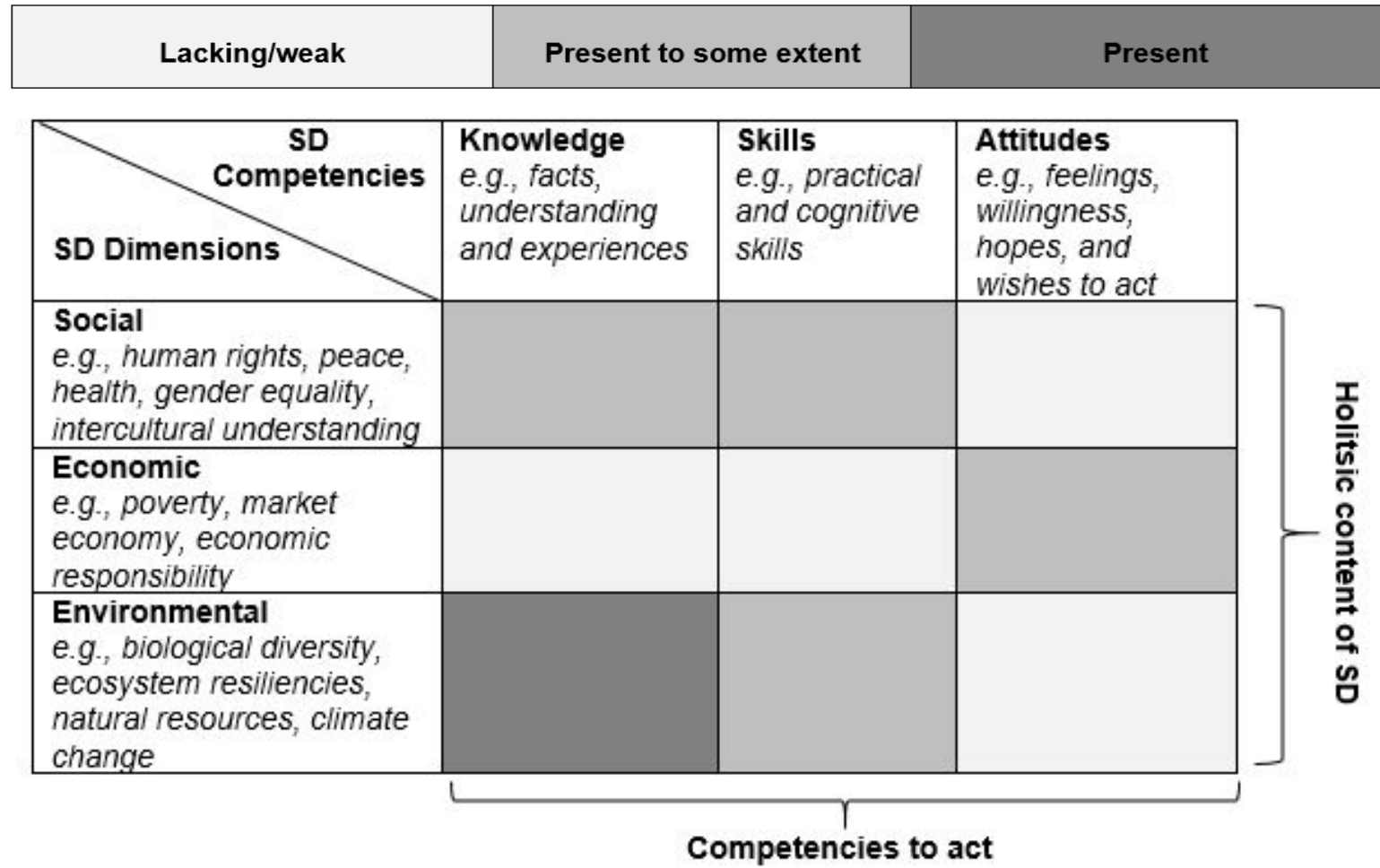

Figure 6. Summary of the results on students' sustainability consciousness. Light grey indicates lacking or weak, medium grey indicates present to some extent, and dark grey indicates present.

As seen in Figure 6, the students' expressions of SD were predominantly monodimensional, from the environmental perspective; there were a few examples of social perspectives, but the economic perspective was very vague. There were some examples of bi-dimensional understanding, including the environmental and the social dimension but lacking the economic dimension. However, their motivation to act (attitudes) was highest within the economic dimension. The skills they claimed to have acquired were mainly practical and mostly within the environmental dimension, only to some extent in the social. 


\section{What characterizes the teaching in the ESD project the students participated in?}

To answer the second research question, data from teachers' project description, group interview with teachers, and the cross-form from the students were analyzed. From the teachers' project description, the ESD project fulfilled the guidelines in terms of including several subjects, namely science, sport, and outdoor life. It may also be described as inquiry-based teaching, in which the students were engaged in activities such as diagnosing problems, identifying questions, searching for information, collecting evidence, planning investigations, researching conjectures, interpreting evidence, formulating explanations, communicating findings, debating with peers, and forming coherent arguments (Lee, Linn, Varma, \& Liu, 2010). Part of the teaching was conducted outdoors, and learning arenas in the local environment were used.

From the observations of students' oral presentations and the student interviews, it was confirmed that the students had clearly been engaged in inquiry activities, especially related to the fieldwork and the trip, but also in the processes of analyzing their results, writing a report, and presenting to their peers and teachers. Students confirmed that the practical work and the work conducted afterward impacted on their learning.

Sofie: Yes, so, I think ... well, I didn't really understand much when we were conducting the fieldwork and doing the gradient analysis. But afterward, when we wrote the report, I started to understand and to learn some things.

Ida: Well, I felt I learned some things already when we were doing the fieldwork, when we were lying there in the heather and studying the lichens and other organisms. We learned the names of the different lichens.

Interviewer: Yes. How did you learn that, then?

Ida: $\mathrm{Er}, \ldots$ you learn a lot just from seeing them in real life, and the supervisors told us the names.

The students explicitly related their learning to the experiences and practical work.

Interviewer: So if you hadn't been on the trip, do you think you would have learned the same in the classroom?

Sofie: It would have been more difficult, because we would not have seen all of these different species and their environment.

Marie: I agree, at least when we learned about so many different types of lichen and so on, I don't think ... there were many students who would have remembered much from seeing them on a PowerPoint at school.

In the analysis of the cross-form, there appeared to be a discrepancy between the 16 competencies (six knowledge, four attitudes, six skills) the teachers claimed 
were taught and trained, and the students' perception. The highest match in the category knowledge was $82 \%$, and $62.5 \%$ within the category attitudes. The lowest match was within skills, with an average match of 53\%, but this was also where the greatest variation was found. Half of the statements had less than $50 \%$ match and the other half more than 50\%.

The teachers described the ESD project as multidisciplinary, including both multiple subjects and multiple teachers. In the interview, the teachers explained how they saw the possibilities for focusing on SD in the local environment when they developed the ESD project:

Gunnar: We have been on these kinds of trips before, but perhaps mostly just to do some outdoor activities. So we saw some opportunities there. And when we integrated SD into them ... we certainly saw this could be an exciting project. The national park has been a topic of debate in the local newspapers for a while, with regard to human activity versus outdoor recreation and nature protection ...

But, during the interview, the teachers recognized that, in their keenness to use the local environment as a learning arena and create conditions for the students to engage in inquiry, the holistic approach of SD might have been under-communicated.

Knut: I realized that we could have focused more on sustainability connected to outdoor life and reflection around that part too.

Gunnar: I think that the situation allowed too little time for collaboration ... In that case, it really is up to the individual teacher.

The teachers acknowledged that collaboration between them had not been as extensive as they had intended. When reflecting on the content related to SD, they concluded that their teaching had mainly been dominated by science.

\section{Summary of Results on RQ2: What characterizes the teaching in the ESD project the students participated in?}

By triangulating the results from the cross-form, the group interview with the teachers and the project descriptions, the results can be summarized as follows: The design of the ESD project met the guidelines that were given in Year 1 of participation in the Sustainable Backpack program. However, although several teachers and subjects were included, the teaching seemed to have been multidisciplinary rather than interdisciplinary, and dominated by science. The teachers gave the impression of having a holistic understanding of the interdisciplinarity of sustainable development and the importance of integrating the three perspectives into the topic for the ESD project. Yet, the holistic approach of SD seemed to have been under-communicated and not explicitly thought through. There was a quite large gap between the students' outcomes and the teachers' intentions. 


\section{Redesign and Evaluation}

The redesign of the ESD project resulted in several changes, as explained by the teachers in the interview.

Kari: We are now preparing the students better for the trip and fieldwork, and we have a whole day for this preparation. We also emphasize collaborative learning between the students more. In the preparation session, they must reflect, discuss, and plan what it takes to go on an overnight trip out in the mountains for two days. They may plan for [setting up] the campsite, the cooking, what equipment we need, and how to be in nature without leaving traces of our presence.

Something else the teachers wanted to improve from the previous year was to be more explicit about the objectives of the learning activities and what the expected learning outcomes were for the students. Another important change was collaboration between subjects, which resulted in including Norwegian as a subject and the Norwegian subject teacher.

\section{Students' Sustainability Consciousness}

The redesigned ESD project was implemented the following school year (school year 3). The participants were 21 students from grade 11 (first grade of upper secondary school, age 16) and three teachers of science, sport, mathematics and Norwegian. The only source of data on students' outcomes after the redesign is the survey, which was answered by the 21 students.

The results from the survey show that 19 out of 21 students knew the correct Brundtland definition of SD and 13 out of 21 students (62\%) knew that SD is about environmental, social, and economic elements. Only eight answered that sustainability involves only the environment, animals, and plants. This result indicates that the majority of the students had a tri-dimensional understanding, that is, all three dimensions were considered. Ten students agreed with the statement that $S D$ is about saving nature at any cost, whereas only one disagreed and 11 neither agreed nor disagreed. This suggests that the majority of the students were unsure about SD being tri-dimensional. However, 18 students agreed that $S D$ is about finding compromises that take into account both social and economic conditions for people while protecting nature, indicating a tri-dimensional, integrated understanding. Five students agreed with the statement that $S D$ is about doing what is best for human beings. These answers also indicate a monodimensional understanding but from a social point of view. However, the majority of the students $(\mathrm{n}=9)$ neither agreed nor disagreed with this statement. Eleven students agreed with the statement that There is a difference between working for $S D$ and being an environmentalist, while three disagreed. Again, this shows that the majority of the students understood that SD differs from nature conservation and that $\mathrm{SD}$ is more than mono-dimensional. 


\section{Discussion}

The purpose of this qualitative case study was to explore students' outcomes from participating in an education for sustainable development (ESD) project and hence try to explain these outcomes.

The results show that, with regard to the content dimension of students' sustainability consciousness, they mainly expressed a mono-dimensional perception from the environmental perspective. The students only occasionally expressed a bi-dimensional perception and hardly any tri-dimensional perception. The bi-dimensional mainly encompassed the environmental and the social perspectives. It would seem that these results are not exceptional in any way, neither for students (Manni et al., 2013) nor for teachers (Borg, Gericke, Höglund, \& Bergman, 2012, 2014). In the study by Olsson et al. (2016), the students achieved highest on the social dimension in the survey, but it was within the environmental dimension that the differences were greatest. ESD schools had a larger score on the environmental dimension than ESD schools without an ESD profile, a result that may be explained by the fact that the environmental dimension is the most recognized among upper secondary teachers (Borg et al., 2014). This could also explain the result of this study; however, the result could also be explained by a lack of explicit teaching, such as Manni et al. (2013) called for in the discussion of their study. This explanation is given credibility by the results from the second data collection, which showed that the students' sustainability consciousness seemed improved after the redesign of the ESD project. One of the main changes in the redesign was explicit teaching and learning goals and Norwegian as an additional subject.

From an earlier study, Munkebye (2016) analyzed ESD projects in the Sustainable Backpack for students aged six to nine, and found that Norwegian was important and contributed basic skills necessary for students to learn about SD. This could explain the improved results in the second year of this study as well.

Another interesting finding was that, although there was little sign of a holistic perception of SD among the students, when talking about their main interest, alpine skiing, they started to consider more dimensions than the environmental, in particular the social dimension. This finding indicates the importance of linking themes of SD to what is familiar and personal to the students. This conclusion is supported by the study of Gabrielsen and Korsager (2018), who found that teachers supported the use of the local environment as a learning arena in ESD in order to engage the students and have a positive impact on their attitudes towards actions for SD. Distance, in terms of both time and space, can be an obstacle for engagement, because the students do not feel it is their concern or it becomes too abstract (Stoknes, 2014, 2015). However, even though the students in this study were working with sustainability issues in their local environment, there seemed 
to be a need for it to become more personal for them to start expressing more holistic approaches to SD.

With regard to the students' competencies to act, what the students know about how they can contribute to SD scored much higher than what they want to do. In other words, their knowledge and awareness seemed greater than their attitudes and willingness. There is no obvious explanation for this finding, but again it could be a lack of engagement and the feeling on the part of the students that they did not have a responsibility to take action. Other studies also show that a lack of engagement in environmental and sustainable issues is not uncommon (Kaplan \& Kaplan, 2002; Liefländer \& Bogner, 2014; Negev, Sagy, Garb, Salzberg, \& Tal, 2008; Uitto \& Saloranta, 2010).

The findings from this study also show that the students frequently express joy and interest when they talk about the field trip and the work they did in the outdoors. Although there is no direct link between the affective values and students' actual contributions to SD, several studies show that teaching outside the classroom can help achieve learning goals in SD (Manni et al., 2013). However, this study shows that, despite the students' explicit express pleasure in undertaking the trip and being outdoors, this was not directly correlated with their engagement and motivation for SD.

When analyzing both the design and the implementation of the ESD project, several factors were found which could be possible explanations for the students' sustainability consciousness found in this study. Both a lack of collaboration between the teachers and a lack of explicit teaching could explain why a holistic approach to SD was under-communicated to the students. The teachers argued that this was partly because there was little culture of collaboration in the school and partly because there had been too little time for them to collaborate and plan their teaching. This is a common challenge for teachers (Borg et al., 2012; Pharo et al., 2012). Even teachers who manage to collaborate across subjects around interdisciplinary topics report being overworked and unable to dedicate the time they would ideally require for the purpose (Gayford, 2002; Sjøberg, Jorde, Haldorsen, \& Lea, 1995). This often results in less collaboration over time and a culture in which teachers tend to maintain the integrity of their subject or neglect subject areas beyond their main expertise, which might nevertheless be important dimensions of the interdisciplinary topic they teach (Pharo et al., 2012). Several studies indicate that individual teachers find it difficult to integrate the three dimensions in their own understanding and hence it is unlikely that they will employ a holistic approach (Borg et al., 2014; Giddings, Hopwood, \& O'Brien, 2002). However, this issue is related to teachers' competencies to teach SD, rather than to how many subjects are included in the ESD project or how many teachers are collaborating in it (Dale \& Newman, 2005; Feng, 2012, p. 32; Jegstad \& Sinnes, 2015). 


\section{Summary, Conclusion, and Implications}

In summary, the impact on students' sustainability consciousness of participating in this ESD project was neither exceptional nor insignificant. The students expressed some knowledge, skills, and motivation related to SD. With younger pupils, results such as heightened interest, joy, enthusiasm for nature, and awareness of the possibilities of action for SD could be regarded as satisfying outcomes and steps on the way to their becoming citizens who can reflect on and contribute their own actions to SD. However, many students in upper secondary school are close to leaving the educational system and are already expected to be such responsible citizens. It is therefore desirable that their sustainability consciousness is more comprehensive and that they have a holistic perception of SD.

It may be complex to design and carry out ESD projects to improve students' sustainability consciousness. This study is not an ideal example of an ESD project, but the results highlight that explicit teaching with a holistic perspective of SD, including affective aspects, are important means of raising students' sustainability consciousness. The results suggest the need for more collaboration between teachers and for interdisciplinary teaching in ESD projects. However, the authors would rather recommend focusing on the holistic perspective of SD, whatever the number of subjects, number of teachers, or opportunities to collaborate. This suggestion implies a need to upgrade all teachers' competencies to teach SD.

The process of implementing ESD at an international and national level has been ongoing for some time, with varied results. Now, the necessity for a joint effort to promote SD on the part of the entire human population has become a top priority, and education is likely the most significant arena for empowering people to act. In Norway, there is currently a process of renewing the school curricula (valid from autumn 2020), and SD is one of three interdisciplinary topics in the new curricula. The government (Kunnskapsdepartementet, 2016) clarifies that this topic needs to be taught across several subjects to give the students understanding of current societal challenges and dilemmas, as well as of the connection between actions and choices and how they can find solutions through acquiring knowledge and using technology (Kunnskapsdepartementet, 2016). In science, it has also been decided that teaching should be more coherent and context-based and should place more emphasis on using the environment as a learning arena (Kunnskapsdepartementet, 2018).

This can enable more affective aspects in education, which are shown to be important to empower learners. However, in order for these curricula to be successfully implemented, all teachers need competencies to teach SD holistically. 


\section{About the authors}

Majken Korsager is associate professor at the Norwegian Centre for Science Education. She is a trained biologist, and has a doctorate in science education. She has in recent years worked on the development of resources and teacher training in education for sustainable development and inquiry based science teaching. Institutional Affiliation: Norwegian Centre for Science Education, University of Oslo, Sem Sælands vei 24, 0371 Oslo.

Email: majken.korsager@naturfagsenteret.no

Eldri Scheie is associate professor at the Norwegian Centre for Science Education. She has led the professional development for teachers nationwide in the Sustainable Backpack since 2009, as well as at several levels from policy to school leaders. Scheie is a trained engineer in biotechnology, has a doctorate in photosensibility and several years of experience teaching in upper secondary school. She has in recent years worked on the development of resources and teacher training with a focus on inquiry based and interdisciplinary teaching for sustainable development.

Institutional Affiliation: Norwegian Centre for Science Education, University of Oslo, Sem Sælands vei 24, 0371 Oslo.

Email: eldri.scheie@,naturfagsenteret.no

\section{References}

Berglund, T., Gericke, N., \& Chang Rundgren, S.-N. (2014). The implementation of education for sustainable development in Sweden: Investigating the sustainability consciousness among upper secondary students. Research in Science \& Technological Education, 32(3), 318-339.

Borg, C., Gericke, N., Höglund, H.-O., \& Bergman, E. (2012). The barriers encountered by teachers implementing education for sustainable development: Discipline bound differences and teaching traditions. Research in Science \& Technological Education, 30(2), 185-207.

Borg, C., Gericke, N., Höglund, H.-O., \& Bergman, E. (2014). Subject- and experience-bound differences in teachers' conceptual understanding of sustainable development. Environmental Education Research, 20(4), 526-551.

Breiting, S., \& Mayer, M. (2015). Quality Criteria for ESD Schools: Engaging Whole Schools in Education for Sustainable Development. In R. Jucker \& R. Mathar (Eds.), Schooling for Sustainable Development in Europe: Concepts, policies and educational experiences at the end of the UN decade of education for sustainable development (pp. 31-46). Cham, Switzerland: Springer.

Breiting, S., Mayer, M., \& Mogensen, F. (2005). Quality criteria for ESD schools: Guidelines to enhance the quality of education for sustainable development. Vienna: Stollfuß Verlag.

Breiting, S., \& Mogensen, F. (1999). Action competence and environmental education. Cambridge Journal of Education, 29(3), 349-353. 
Corney, G. (2006). Education for sustainable development: An empirical study of the tensions and challenges faced by geography student teachers. International Research in Geographical and Environmental Education, 15(3), 224-240.

Dale, A., \& Newman, L. (2005). Sustainable development, education and literacy. International Journal of Sustainability in Higher Education, 6(4), 351-362.

De Corte, E. (2010). Historical developments in the understanding of learning. In H. Dumont, D. Istance, \& F. Benavides (Eds.), The nature of learning. Using research to inspire practice (pp. 35-67). Paris: OECD Publishing.

De Haan, G. (2006). The BLK '21' programme in Germany: A 'Gestaltungskompetenz'based model for Education for Sustainable Development. Environmental Education Research, 12(1), 19-32.

Erstad, O., Amdam, S., Arnseth, H. C., \& Silseth, K. (2014). Om fremtidens kompetansebehov. En systematisk gjennomgang av internasjonale og nasjonale initiativ [Competencies for the future. A systematic review of international and national initiatives]. Oslo: Universitetet i Oslo.

Feng, L. (2012). Teacher and student responses to interdisciplinary aspects of sustainability education: What do we really know? Environmental Education Research, 18(1), 31-43.

Gabrielsen, A., \& Korsager, M. (2018). Nærmiljø som læringsarena i undervisning for bærekraftig utvikling. En analyse av læreres erfaringer og refleksjoner [Local environment as learning arena for teaching sustainable development. An analysis of teachers' experiences and reflections]. Nordic Studies in Science Education, 14(4), 335-349.

Gayford, C. (2002). Controversial environmental issues: A case study for the professional development of science teachers. International Journal of Science Education, 24(11), 1191-1200.

Giddings, B., Hopwood, B., \& O'Brien, G. (2002). Environment, economy and society: Fitting them together into sustainable development. Sustainable Development, 10(4), 187-196.

Heckman, J., \& Kautz, T. (2013). Fostering and measuring skills: Interventions that improve character and cognition. Working Paper 19656. Massachusetts: National Bureau of Economic Research.

Hesselink, F., van Kempen, P. P., \& Wals, A. (2000). ESDebate: International on-line debate on Education for Sustainable Development. Gland, Switzerland: International Union for the Conservation of Nature.

Jegstad, K. M., \& Sinnes, A. T. (2015). Chemistry teaching for the future: A model for secondary chemistry education for sustainable development. International Journal of Science Education, 37(4), 655-683.

Jensen, B. B., \& Schnack, K. (1997). The action competence approach in environmental education. Environmental Education Research, 3(2), 163-178.

Kaplan, R., \& Kaplan, S. (2002). Adolescents and the natural environment: A time out. In P. Kahn \& S. Kellert (Eds.), Children and Nature: Psychological, Sociocultural, and Evolutionary Investigations (pp. 227-257). London: MIT Press Cambridge.

Kollmuss, A., \& Agyeman, J. (2002). Mind the gap: Why do people act environmentally and what are the barriers to pro-environmental behavior? Environmental Education Research, $8(3), 239-260$.

Koppelman, J. (2013). Are we really Educating about Sustainability? Journal of Sustainability Education, June 2013. Retrieved July 3, 2019 from

http://www.jsedimensions.org/wordpress/content/are-we-really-educating-aboutsustainability 2013 06/

Kunnskapsdepartementet (2016). Meld. St. 28 (2015-2016). Fag - Fordypning - Forståelse: En fornyelse av Kunnskapsløftet [Subjects - Specialization - Understanding. A renewal of 
the Knowledge Promotion]. Oslo: The Ministry of Education and Research. Retrieved from https://www.regjeringen.no/no/dokumenter/meld.-st.-28-20152016/id2483955/

Kunnskapsdepartementet (2018). Kjerneelementer i fag [Core elements in subjects]. Retrieved from https://www.regjeringen.no/contentassets/3d659278ae55449f9d8373fff5de4f65/kjerneele menter-i-fag-for-utforming-av-lareplaner-for-fag-i-lk20-og-lk20s-fastsatt-av-kd.pdf

Lafuente, R., \& Sánchez, M. (2010). Defining and measuring environmental consciousness. Revista Internacional de Sociología, 68(3), 731-755.

Lee, H. S., Linn, M. C., Varma, K., \& Liu, O. L. (2010). How do technology-enhanced inquiry science units impact classroom learning? Journal of Research in Science Teaching, 47(1), 71-90.

Liefländer, A. K., \& Bogner, F. X. (2014). The effects of children's age and sex on acquiring pro-environmental attitudes through environmental education. The Journal of Environmental Education, 45(2), 105-117.

Manni, A., Ottander, C., Sporre, K., \& Parchmann, I. (2013). Perceived learning experiences regarding education for sustainable development - within Swedish outdoor education traditions. Nordic Studies in Science Education, 9(2), 187-205.

Mogensen, F., \& Schnack, K. (2010). The action competence approach and the 'new' discourses of education for sustainable development, competence and quality criteria. Environmental Education Research, 16(1), 59-74.

Munkebye, E. (2016). Implementation of education for sustainable development in primary schools - in a Norwegian perspective. In L. Tuszyńska (Ed.), Koncepcja zrównoważonego rozwoju w kształceniu nauczycieli klas poczatkowych (pp. 67-83). Retrieved from http://www.aps.edu.pl/media/815706/koncepcja-zr\%C3\%B3wnowa\%C5\%BConegorozwoju-w-kszta\%C5\%82ceniu-nauczycieli.pdf

Negev, M., Sagy, G., Garb, Y., Salzberg, A., \& Tal, A. (2008). Evaluating the environmental literacy of Israeli elementary and high school students. The Journal of Environmental Education, 39(2), 3-20.

Ohman, J., Ostman, L., \& Sandell, K. (2005). Education for sustainable development: Nature, school and democracy. Lund: Studentlitteratur.

Olsson, D., Gericke, N., \& Chang Rundgren, S.-N. (2016). The effect of implementation of education for sustainable development in Swedish compulsory schools - assessing pupils' sustainability consciousness. Environmental Education Research, 22(2), 176-202.

Pauw, J. B.-D., Gericke, N., Olsson, D., \& Berglund, T. (2015). The effectiveness of education for sustainable development. Sustainability, 7(11), 15693-15717.

Pharo, E., Davison, A., Warr, K., Nursey-Bray, M., Beswick, K., Wapstra, E., \& Jones, C. (2012). Can teacher collaboration overcome barriers to interdisciplinary learning in a disciplinary university? A case study using climate change. Teaching in Higher Education, 17(5), 497-507.

Prøitz, T. S. (2014). Conceptualisations of learning outcomes in education - an explorative cross-case analysis of policymakers, teachers and scholars. $\mathrm{PhD}$ thesis, University of Oslo.

Rychen, D. S., \& Salganik, L. H. (2003). A holistic model of competence. In D. S. Rychen \& L. H. Salganik (Eds.), Defining and selecting key competencies (pp. 41-62). Seattle: Hogrefe \& Huber.

Schneider, M., \& Stern, E. (2010). The cognitive perspective on learning: Ten cornerstone findings in Dumont. In H. D. Istance \& F. Benavides (Eds.), The nature of learning: Using research to inspire practice (pp. 69-90). Paris: OECD Publishing.

Silverman, D. (2009). Doing qualitative research: A practical handbook. London: Sage. 
Sjaastad, J., Carlsten, T. C., Opheim, V., \& Jensen, F. (2014). Evaluering av Den naturlige skolesekken: Utdanning for borekraftig utvikling på ulike loeringsarenaer [Evaluation of The sustainable backpack: Education for sustainable development in diverse learning arenas]. NIFU-rapport 2014:38. Retrieved from https://www.nifu.no/publications/1177183/

Sjøberg, S., Jorde, D., Haldorsen, K., \& Lea, A. (1995). Naturfagutredningen [Report on Science in School]. Oslo: Norwegian Ministry of Education, Research and Church Affairs, and University of Oslo.

Skolverket (2013). Betydelsen av icke-kognitiva förmågor. Forskning m.m. om individuella faktorer bakom framgång [The importance of non-cognitive abilities. Research etc. on individual factors behind success]. Sweden: Skolverket. Retrieved from https://www.skolverket.se/publikationer?id=2981

Stoknes, P. E. (2014). Rethinking climate communications and the "psychological climate paradox". Energy Research \& Social Science, 1, 161-170.

Stoknes, P. E. (2015). What we think about when we try not to think about global warming: Toward a new psychology of climate action. Chelsea: Green Publishing.

Summers, M., \& Childs, A. (2007). Student science teachers' conceptions of sustainable development: An empirical study of three postgraduate training cohorts. Research in Science \& Technological Education, 25(3), 307-327.

Uitto, A., \& Saloranta, S. (2010). The relationship between secondary school students' environmental and human values, attitudes, interests and motivations. Procedia - Social and Behavioral Sciences, 9, 1866-1872.

UN (2015). Transforming our world: The 2030 agenda for sustainable development. Resolution adopted by the General Assembly. Retrieved from https://sustainabledevelopment.un.org/content/documents/21252030\%20Agenda $\% 20$ for $\%$ 20Sustainable\%20Development $\% 20 \mathrm{web} . \mathrm{pdf}$

UNECE (2011). Learning for the future: Competences in Education for Sustainable Development. United Nations Economic Commission for Europe, Steering Committee on Education for Sustainable Development. Retrieved from https://www.unece.org/fileadmin/DAM/env/esd/ESD_Publications/Competences_Publica tion.pdf

UNESCO (2005). UN decade of education for sustainable development (2005-2014). Paris. Retrieved from http://unesdoc.unesco.org/images/0014/001416/141629e.pdf

UNESCO (2006). Framework for the UN DESD international implementation scheme. Retrieved from http://unesdoc.unesco.org/images/0014/001486/148650e.pdf

UNESCO (2017). Education for Sustainable Development Goals: Learning Objectives. Retrieved from http://unesdoc.unesco.org/images/0024/002474/247444e.pdf

Utdanningsdirektoratet (2010). Lareplanverket for Kunnskapsløftet. Den generelle delen av laereplanen [Core curriculum and the quality framework]. Oslo.

Utdanningsdirektoratet (2006). Laereplanverket for Kunnskapsløftet [The curriculum for the Knowledge Promotion]. Retrieved from https://www.udir.no/laring-ogtrivsel/lareplanverket/

Van den Bergh, J. C. J. M. (2007). Sustainable development in ecological economies. In G. Atkinson, S. Dietz, \& E. Neumayer (Eds.), Handbook of sustainable development (pp. 63-77). Cheltenham: Edward Elgar Publishing Ltd.

Vare, P., \& Scott, W. (2007). Learning for a change: Exploring the relationship between education and sustainable development. Journal of Education for Sustainable Development, 1(2), 191-198.

Wals, A. E. (2011). Learning our way to sustainability. Journal of Education for Sustainable Development, 5(2), 177-186. 
Wals, A. E. (2012). Shaping the education of tomorrow: 2012 full-length report on the UN decade of education for sustainable development. UNESCO. Retrieved from https://library.wur.nl/WebQuery/wurpubs/fulltext/246667

WCED (1987). Report of the World Commission on Environment and Development. London: Oxford University Press. Retrieved from http://www.un-documents.net/our-commonfuture.pdf

Weinert, F. E. (2001). Concept of competence: A conceptual clarification. In D. Rychen \& L. H. Salganik (Eds.), Defining and selecting key competencies (pp. 45-65). Seattle and Göttingen: Hogrefe \& Huber. 